\title{
Diel oscillations in the feeding activity of heterotrophic and mixotrophic nanoplankton in the North Pacific Subtropical Gyre
}

\author{
Paige E. Connell ${ }^{1,4}$, François Ribalet ${ }^{2}$, E. Virginia Armbrust ${ }^{2}$, Angelicque White ${ }^{3}$, \\ David A. Caron ${ }^{1, *}$ \\ ${ }^{1}$ Department of Biological Sciences, University of Southern California, Los Angeles, CA 90089-0371, USA \\ ${ }^{2}$ School of Oceanography, University of Washington, Seattle, WA 98195, USA \\ ${ }^{3}$ Department of Oceanography, University of Hawai'i at Mānoa, Honolulu, HI 96822, USA \\ ${ }^{4}$ Present address: San Diego Mesa College, 7250 Mesa College Drive, San Diego, CA 92111-4998, USA
}

\begin{abstract}
Daily oscillations in photosynthetically active radiation strongly influence the timing of metabolic processes in picocyanobacteria, but it is less clear how the light-dark cycle affects the activities of their consumers. We investigated the relationship between marine picocyanobacteria and nanoplanktonic consumers throughout the diel cycle to determine whether heterotrophic and mixotrophic protists (algae with phagotrophic ability) display significant periodicity in grazing pressure. Carbon biomass of Prochlorococcus and Synechococcus was estimated continuously from abundances and cell size measurements made by flow cytometry. Picocyanobacterial dynamics were then compared to nanoplankton abundances and ingestion of fluorescently labeled bacteria measured every $4 \mathrm{~h}$ during a $4 \mathrm{~d}$ survey in the North Pacific Subtropical Gyre. Grazing of the labeled bacteria by heterotrophic nanoplankton was significantly greater at night than during the day. The grazing activity of mixotrophic nanoplankton showed no diel periodicity, suggesting that they may feed continuously, albeit at lower rates than heterotrophic nanoplankton, to alleviate nutrient limitation in this oligotrophic environment. Diel changes in Prochlorococcus biomass indicated that they could support substantial growth of nanoplankton if those grazers are the main source of picocyanobacterial mortality, and that grazers may contribute to temporally stable abundances of picocyanobacteria.
\end{abstract}

KEY WORDS: Picocyanobacteria $\cdot$ Nanoplankton grazing $\cdot$ Bacterivory $\cdot$ Diel cycles $\cdot$ Mixotrophy

\section{INTRODUCTION}

Marine picoplanktonic $(0.2-2 \mu \mathrm{m})$ cyanobacteria are the most abundant phototrophic organisms on the planet, with an estimated global population abundance of $\sim 10^{27}$ cells (Flombaum et al. 2013). Marine picocyanobacteria comprise primarily 2 genera, Prochlorococcus and Synechococcus, which are estimated to have diverged from a common ancestor approximately 150 million years ago (Dufresne et al. 2005). Since that time, they have diversified into multiple clades (Ahlgren \& Rocap 2012, Biller et al. 2015),

${ }^{*}$ Corresponding author: dcaron@usc.edu each defined by morphology, physiology, genomic similarity, and environmental niche. Synechococcus has a wider global distribution, owing to its greater capacity to tolerate cold temperatures (Pittera et al. 2014) and metal contamination (Mann et al. 2002). Prochlorococcus dominates in warm, oligotrophic regions, with cells inhabiting all portions of the euphotic zone in the upper ocean (Partensky et al. 1999).

These abundant and diverse phytoplankton genera are critical components of the earth's biogeochemical cycles and marine food webs. Approximately $50 \%$ of global oxygen production is a result of photosynthesis

() The authors 2020. Open Access under Creative Commons by Attribution Licence. Use, distribution and reproduction are unrestricted. Authors and original publication must be credited. 
in the ocean (Field et al. 1998), with approximately a quarter of that fraction attributable to picocyanobacteria. Synechococcus and Prochlorococcus biomass also supports considerable secondary production by planktonic consumers capable of capturing and ingesting pico-sized prey in warm oceanic regimes (Landry \& Calbet 2004). Therefore, it is critical to characterize the trophic relationship between the marine picocyanobacteria and the organisms that consume them for understanding ecosystem dynamics and biogeochemical fluxes in the marine environment.

Protistan grazers are a predominant source of microbial mortality in marine environments (Sherr \& Sherr 2002, Calbet \& Landry 2004) and an important source of regenerated nutrients and dissolved organic matter for phytoplankton and bacterial assemblages (Caron \& Goldman 1990). Protists display a diverse array of nutritional strategies, including species that meet all growth requirements via phagotrophy. Other species combine heterotrophic and phototrophic nutrition (mixotrophy) to meet various nutritional requirements that might include energy, carbon, macronutrients $(\mathrm{N}, \mathrm{P})$, micronutrients (e.g. Fe), or vitamins (Liu et al. 2016, Stoecker et al. 2017). This diversity of nutritional needs may result in different short-term responses of grazers to diel fluctuations in prey size, abundance, biomass, or cellular composition.

The relationship between diel changes in the activity levels of picoplanktonic cyanobacteria and the activities of their consumers throughout the lightdark cycle is not well defined. Field observations of maximal picocyanobacterial division at dusk, coupled with observations that indicate relatively stable day-to-day population abundances, have indicated that cyanobacterial mortality (viral- and/or grazermediated) may be highest at night and lowest during the day, at least during the fall season in the North Pacific Subtropical Gyre (NPSG) (Ribalet et al. 2015). However, few studies have directly investigated changes in protistan grazing pressure throughout the diel cycle, and those investigations have yielded contradictory findings. Some studies have suggested that grazing pressure on picoplanktonic prey by nanoplanktonic $(2-20 \mu \mathrm{m})$ protistan consumers is highest at night because the probability of encountering prey increases due to the presence of newly divided cyanobacterial cells (Christaki et al. 2002, Tsai et al. 2009). Alternatively, Deng et al. (2020) reported higher grazing rates during the night for the heterotrophic dinoflagellate Oxyrrhis marina preying on the cyanobacterium Crochosphaera watsonii, a result they attributed to improved nutritional qual- ity of the prey as a result of nighttime nitrogen fixation. Other studies have reported higher grazing pressure during the day, citing preferential grazing on small, post-division cells early in the day (Dolan \& Simek 1999) or compensatory feeding on low quality prey (i.e. higher C:N ratios) ( $\mathrm{Ng} \&$ Liu 2016) as possible explanatory factors. Most of these investigations have examined the ingestion of picoplankton by heterotrophic nanoplankton, although a few reports have examined the influence of the diel cycle on feeding by small phagotrophic (mixotrophic) phytoflagellates (Urabe et al. 2000, Anderson et al. 2017). These studies suggest that diel fluctuations in grazing activity of protists can be important, but the timing of peak grazing activity appears to vary with environmental conditions.

We investigated the relationship between marine picocyanobacteria and their nanoplanktonic protistan consumers throughout the diel cycle in the NPSG. Measurements of population abundances, carbon biomass, and grazing pressure (measured via the ingestion of fluorescently labeled prey) were conducted at regular time intervals $(\sim 4 \mathrm{~h})$ over a $4 \mathrm{~d}$ period. We specifically sought to determine whether nanoplankton grazing pressure exhibited diel periodicity, and if so, whether this periodicity was similar for heterotrophic nanoplankton (HNAN) and mixotrophic nanoplankton (MNAN). Additionally, we examined the potential contribution of picocyanobacterial biomass to nanoplankton growth. Significant diel periodicity in grazing pressure of HNAN was observed that closely followed the peak of picocyanobacterial carbon biomass, while MNAN demonstrated no diel periodicity in their grazing pressure. The disparate nutritional requirements of heterotrophic and mixotrophic consumers may explain the different responses of the 2 consumer assemblages.

\section{MATERIALS AND METHODS}

\subsection{Sampling and environmental metadata}

Water collection occurred from 26-30 July 2015 on cruise KM1513 within an anticyclonic eddy $\sim 100 \mathrm{~km}$ northeast $\left(\sim 24.4^{\circ} \mathrm{N}, 156^{\circ} \mathrm{W}\right)$ of the long-term timeseries Stn ALOHA $\left(22.75^{\circ} \mathrm{N}, 158^{\circ} \mathrm{W}\right)$ in the NPSG (Fig. 1). A Lagrangian sampling scheme was conducted using World Ocean Circulation Experiment Surface Velocity Profile drifters drogued at $15 \mathrm{~m}$ (sampling depth). Shipboard measurements were made alongside the drifters every $4 \mathrm{~h}$ throughout the study period to characterize the diel variability 


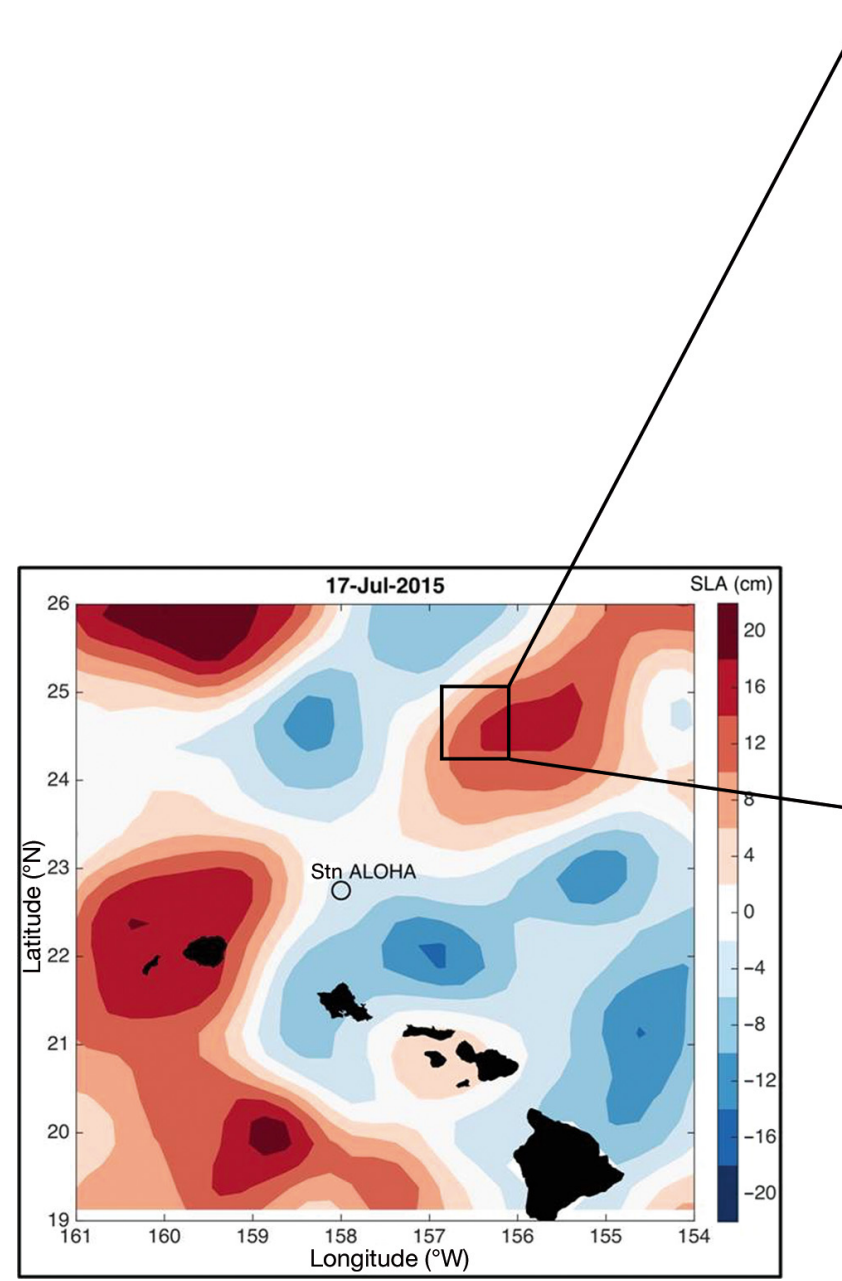

in microbial abundances and activities at the study site. Water for incubations (Section 2.2) was collected at a depth of $15 \mathrm{~m}$ using a $24 \times 121$ Niskin rosette equipped with a CTD (SBE 911Plus, Seabird Electronics), and fluorescence and oxygen sensors, calibrated to discrete chlorophyll (chl) a and phaeopigment measurements and dissolved $\mathrm{O}_{2}$ measurements, respectively.

\subsection{Nanoplankton abundances and relative grazing pressure}

Cell abundances and relative grazing pressure of the nanoplankton (protists, $2-20 \mu \mathrm{m}$ in size) were determined every $4 \mathrm{~h}$ during the study period. The $4 \mathrm{~h}$ sampling interval was dictated by the amount of time required to conduct the hydrocast and process water from the sampling bottles, as well as set up, incubate, and process each experiment (2.5-3 h). Grazing pressures were inferred from a series of incubations in

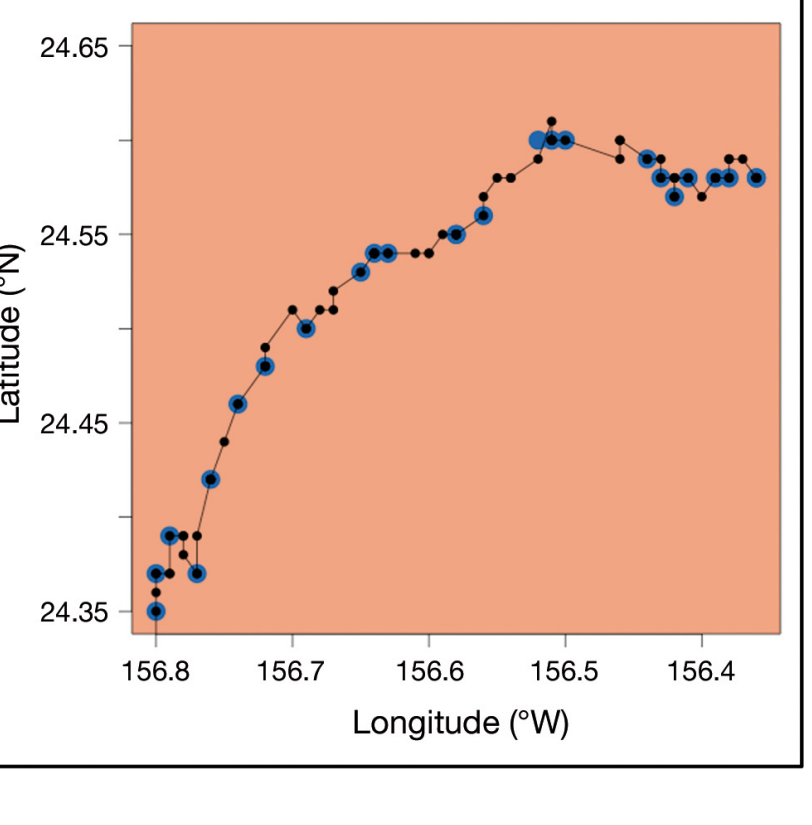

Fig. 1. Study location in the North Pacific Subtropical Gyre, in an anticyclonic eddy northwest of Stn ALOHA. Hawaiian Islands are shown in black, with the sampling area in the black box. SLA: surface layer anomaly (surface height). Enlargement of the black box shows the sampling locations (blue circles) for nanoplankton abundance and grazing impact. The black line shows the Seaflow sampling track, with black points indicating location of hourly averages of picocyanobacterial abundance and division rates. Redrawn from Wilson et al. (2017) with sampling locations pertinent to this study

which the uptake of fluorescently labeled bacteria (FLB) was used as a tracer for the ingestion of natural picoplankton prey (Jürgens \& Massana 2008). FLB were used as surrogate prey for Prochlorococcus (diameter $\sim 0.7 \mu \mathrm{m}$ ) and Synechococcus (diameter $\sim 1.0 \mu \mathrm{m}$ ) in our incubation experiments. FLB were prepared from a monoculture of the rod-shaped bacterium Dokdonia donghaensis, as described previously (Sherr et al. 1987, Caron 2000). This bacterium has been shown to be readily consumed by heterotrophic flagellates (Massana et al. 2009), it is similar in size to the cyanobacterial prey that were the focus of our studies, and it is easily prepared and stored as FLB, and therefore offered a highly reproducible surrogate prey for our work. We have previously employed this species as FLB in oceanic and coastal studies (Connell et al. 2017, 2018). Briefly, D. donghaensis was grown in Zobell Marine Broth (Thomas Scientific) for $2 \mathrm{~d}$, harvested by centrifugation, resuspended in $0.2 \mu \mathrm{m}$ filtered seawater, and incubated in the filtrate for $2 \mathrm{~d}$ to starve the cells. Starving the cells caused cell shrink- 
age, so that the labeled prey would better mimic the size of bacteria and picocyanobacteria observed in natural assemblages (average FLB length $\leq 1 \mu \mathrm{m}$ ). Bacteria were then stained with 5-(4,6-dichlorotriazin-2-yl) aminofluorescein (Invitrogen) and heatkilled, followed by 3 rinses in ultrapure water (Milli-Q Water Purification System, EMD Millipore). FLB were aliquoted and stored at $-80^{\circ} \mathrm{C}$ until used in experiments. FLB used in the study were prepared in a single batch to ensure homogeneity between experiments.

Seawater used in the incubation experiments was transferred directly from a Niskin bottle into triplicate, 2.31 polycarbonate bottles using acid-washed (5\% $\mathrm{HCl}$ ) silicone tubing to prevent bubbling that may harm delicate protistan grazers. Larger grazers in the micro- and mesozooplankton size classes were not removed, as this may lead to an overestimation of nanoplankton grazing impact on picoplankton prey (Calbet \& Landry 1999, Schnetzer \& Caron 2005). The FLB stock was vigorously vortexed and added to each bottle at a target concentration of $1.09 \times 10^{5} \mathrm{FLB} \mathrm{ml}^{-1}$, which corresponds to $15 \%$ of the natural picoplankton abundance (picocyanobacteria + heterotrophic bacteria) in the NPSG (Eiler et al. 2009). Picocyanobacterial abundances remained relatively constant throughout the experiment (Mruwat et al. 2020), but we estimate that, in practice, the FLB:prey ratios varied between approximately 10 and $20 \%$. Bottles were gently mixed to disperse the FLB, and $\mathrm{T}_{0}$, defined as the time of FLB addition, subsamples $(90 \mathrm{ml})$ were removed from each replicate bottle and preserved with formaldehyde (final concentration $1 \%$, final volume $100 \mathrm{ml}$ ). Bottles were incubated in on-deck incubators maintained at in situ temperature and shaded with blue plexiglass to approximate the light level experienced by the microbial assemblage at $15 \mathrm{~m}$. After $1 \mathrm{~h}$ of incubation, triplicate subsamples were collected from each bottle $\left(T_{1 h}\right)$, and preserved subsamples $\left(T_{0}\right.$ and $\mathrm{T}_{1 \mathrm{~h}}$ ) were stored at $4^{\circ} \mathrm{C}$. A $1 \mathrm{~h}$ incubation period was chosen to allow sufficient time for ingestion by trophically active consumers, yet a short enough time that loss of FLB fluorescence due to digestion within food vacuoles would be minimized (Fenchel 1986, Sherr et al. 1987). Time course experiments to determine cellspecific grazing rates, while desirable, were beyond the scope of this project because they require laborintensive time course measurements.

Slides for epifluorescence microscopy were prepared from preserved samples within $12 \mathrm{~h}$ of sampling by filtering the $100 \mathrm{ml}$ subsamples down to $\sim 1 \mathrm{ml}$ onto blackened, $2.0 \mu \mathrm{m}$ pore size, $25 \mathrm{~mm}$ polycarbonate filters to retain nanoplankton but allow most uningested FLB to pass through, and staining the samples with $50 \mu \mathrm{l}$ of a DAPI (Sigma-Aldrich) working solution $\left(1 \mathrm{mg} \mathrm{ml}^{-1}\right)$ for 5-10 min in the dark (Sherr et al. 1993). Stained samples were filtered and rinsed, filters were placed onto glass slides with a drop of immersion oil and a coverslip, and the coverslips were sealed with clear nail polish. Slides were stored at $-20^{\circ} \mathrm{C}$ until analysis using epifluorescence microscopy.

Nanoplankton abundances were enumerated by epifluorescence microscopy at the start of each incubation $\left(\mathrm{T}_{0}\right)$ from the triplicate slides. Photo/mixotrophic nanoplankton (P/MNAN) were distinguished from heterotrophic nanoplankton (HNAN) by the presence or absence of chl a autofluorescence in plastidic structures, respectively, when viewed under blue-light excitation. To quantify the grazing pressure by MNAN and HNAN, 100 cells on each slide were categorized as (1) heterotrophs with no ingested FLB (no chl a fluorescence, no ingested FLB), (2) active heterotrophic grazers of FLB (no chl a fluorescence, ingested FLB), (3) photoautotrophs and/or mixotrophs with no ingested FLB (chl a fluorescence, no ingested FLB), or (4) active mixotrophic grazers of FLB (chl a fluorescence, ingested FLB). Total nanoplankton (TNAN) was the sum of HNAN and P/MNAN. The percentages of HNAN and P/ MNAN that were consuming prey at each sampling time were determined by dividing the number of P/MNAN or HNAN cells with at least 1 FLB by the total number of cells enumerated for the appropriate category. $\mathrm{T}_{1 \mathrm{~h}}$ ingestion percentages for each bottle were corrected by subtracting $\mathrm{T}_{0}$ ingestion percentages from the same bottle, to account for FLB lying near nanoplankton on the slides but not ingested by them. The corrected values were averaged, and standard errors $(n=3)$ were calculated for each timepoint in the diel cycle.

\subsection{Cyanobacterial carbon biomass derived from continuous flow cytometry}

Flow cytometry samples were collected from the continuous seawater flow-through system (fixed sampling depth of $7 \mathrm{~m}$ : Ribalet et al. 2019). Continuous measurements of Prochlorococcus and Synechococcus abundances and light scattering were made using SeaFlow (Swalwell et al. 2011). This system was employed because it provided high temporal resolution of cyanobacterial abundances and sizes throughout the experiment (Prochlorococcus and Synechococcus abundances are presented in Mruwat et al. 2020; see their Fig. 4a and their Supple- 
mental Fig. 4, respectively). Both the depth of the SeaFlow intake and our sampling depth $(15 \mathrm{~m})$ were within the well-mixed surface layer at Stn ALOHA. Our flow cytometric data files from the flow-through system were created every $3 \mathrm{~min}$, and Prochlorococcus and Synechococcus abundances were enumerated using a sequential bivariate manual gating scheme provided by the $\mathrm{R}$ package 'popcycle' version 0.2 .

Light scattering was converted to carbon biomass using an empirical relationship between logarithmicamplified forward light scattering measured by SeaFlow and carbon per cell measured in coccoid or bacilliform shaped picocyanobacteria, namely 4 strains of Prochlorococcus (MED4, CCMP1314, AS9601, and NATL12A), and 2 strains of Synechococcus (WH7803 and WH8102), as well as 4 eukaryotic phytoplankton cultures obtained from the National Center for Marine Algae and Microbiota (Thalassosira pseudonana CCMP3367 and CCMP1135), the Roscoff Culture Collection (Navicula transitans RCC80) or the Canadian Center for the Culture of Microorganisms (Micromonas pusilla). For the determination of carbon per cell, $30 \mathrm{ml}$ of exponentially growing axenic cultures were filtered onto precombusted $25 \mathrm{~mm}$ GF-75 glass fiber filters (nominal porosity $0.3 \mu \mathrm{m}$ ). Particulate carbon concentrations were measured by combustion using an Exeter Analytical CE-440 CHN elemental analyzer, as described by Barone et al. (2015). For each culture, aliquots of growth media were filtered through 3 combusted $25 \mathrm{~mm}$ GF-75 glass fiber filters used as blanks to correct for background carbon concentration on filters before filtration and DOC adsorption onto filters. Carbon per cell was obtained by dividing blankcorrected particulate carbon concentrations by cell abundances measured with a BD Influx cell sorter. The median forward light scattering of the phytoplankton population was normalized by the forward light scattering of $1 \mu \mathrm{m}$ calibration beads (Invitrogen F8823). A non-linear least-squared regression was fit to the mean normalized forward light scattering (FSC) and carbon per cell (QC) using the equation:

$$
\mathrm{QC}=a \times{ }_{\text {norm }} \mathrm{FSC}^{b}
$$

The coefficient $a$ and the exponent $b$, were found to be $2.25 \pm 1.13$ and $1.14 \pm 0.05$, respectively. Estimated mean Qc values for each species were $38 \mathrm{fg} \mathrm{C}$ cell $^{-1}$ (range 23-61 fg C cell ${ }^{-1}$ ) and $233 \mathrm{fg} \mathrm{C} \mathrm{cell}^{-1}$ (range 189-287 $\mathrm{fg} \mathrm{C}^{\mathrm{C}} \mathrm{cell}^{-1}$ ) for Prochlorococcus and Synechococcus, respectively (see Fig. S1 in the Supplement at www.int-res.com/articles/suppl/m085 p167_supp.pdf), which are within the range of values previously reported (see Casey et al. 2013 and references therein). Hourly averaged estimates of cyanobacterial carbon biomass were calculated from the mean of cell abundances multiplied by Qc over a $1 \mathrm{~h}$ period $(\mathrm{N}=20)$.

\subsection{Statistical analyses}

All statistics were computed using $\mathrm{R}$ software ( $\mathrm{R}$ Development Core Team 2015). Significant changes in population abundances throughout the $4 \mathrm{~d}$ period were determined using Welch 2-sample $t$-tests between the initial (26 July 2015, 06:00 h) and final (30 July 2015, 06:00 h) time-points (p-values $<0.05$ were considered to be significant). Significant diel periodicity was determined using the 'RAIN' package, which detects rhythmic rising and falling effects against umbrella alternatives, thereby identifying statistically significant rhythms in time-series data (Thaben \& Westermark 2014). A period of $24 \mathrm{~h}$ was used (RAIN argument $=$ period) with a time difference of $4 \mathrm{~h}$ between sampling points (RAIN argument $=$ deltat). Triplicate values were averaged at each time point, with the average value at each time point used as input to the RAIN algorithm (p-values $<0.05$ were considered to be significant). Peak times were calculated using harmonic regression analysis (custom code; for more detail see Aylward et al. 2015, 2017) for datasets with significant diel periodicity as determined using the RAIN package. Data are presented as means $\pm \mathrm{SE}$.

\section{RESULTS}

Environmental conditions at $15 \mathrm{~m}$ were relatively constant throughout the $4 \mathrm{~d}$ study period (Fig. S2). Water temperature at $15 \mathrm{~m}$ was $26.81 \pm 0.02^{\circ} \mathrm{C}$, with overall temperature ranges for each $24 \mathrm{~h}$ period of $\leq 0.18^{\circ} \mathrm{C}$. Mean salinity was $35.38 \pm 0.001$, with daily ranges of 0.02 . Neither temperature nor salinity showed significant diel rhythmicity at the sampling depth (Fig. S2), which was well within the mixed layer. Dissolved oxygen concentrations averaged $205.7 \pm 0.13 \mu \mathrm{mol} \mathrm{l}^{-1}$, with mean daily fluctuations of $1.85 \mu \mathrm{mol} \mathrm{l}^{-1}$. Dissolved oxygen concentrations generally increased during the day, peaking at dusk, and decreased throughout the night (Fig. S2). Chl a concentrations averaged $0.19 \pm 0.01 \mu g \mathrm{l}^{-1}$ during our study period, and fluctuated by $0.13 \mu \mathrm{g} \mathrm{l}^{-1}$ on average over the diel cycle. Chl a concentrations, derived from fluorescence, decreased from dawn into the early af- 
ternoon, followed by peak concentrations at dusk and during the night (Fig. S2) as is typical of the diurnal cycle of photoacclimation in this region.

Prochlorococcus was the dominant phytoplankter during our study period, with mean abundances of $1.61 \pm 0.11 \times$ $10^{5}$ cells ml $^{-1}$, about 200 -fold greater than that of Synechococcus $(0.86 \pm$ $0.07 \times 10^{3}$ cells ml${ }^{-1}$ ) (Mruwat et al. 2020). Prochlorococcus abundances increased from $1.40 \times 10^{5}$ to $1.80 \times 10^{5}$ cells $\mathrm{ml}^{-1}$ over the $4 \mathrm{~d}$ period $(\sim 20 \%$ increase; $\sim 5 \% \mathrm{~d}^{-1}$ ), while Synechococcus abundances increased from $0.8 \times 10^{3}$ to $0.9 \times 10^{3}$ cells ml $^{-1}(\sim 11 \%$ increase; $\left.\sim 3 \% \mathrm{~d}^{-1}\right)$. Prochlorococcus biomass showed substantial diel periodicities by RAIN analysis $(\mathrm{p}<0.001)$, with increases during the day and into the evening, and decreases throughout the night. Weaker but significant diel periodicity in Synechococcus biomass was also detected $(\mathrm{p}<0.05)$.

TNAN abundance was $313 \pm 11$ cells $\mathrm{ml}^{-1}$, with the community comprising approximately twice as many HNAN (i.e. cells lacking chlorophyll fluorescence, $217 \pm 6$ cells $\mathrm{ml}^{-1}$ ) as P/MNAN (cells exhibiting chlorophyll fluorescence, $97 \pm 8$ cells ml$^{-1}$ ) during the study period (Fig. 2). The abundances of both nanoplankton assem-
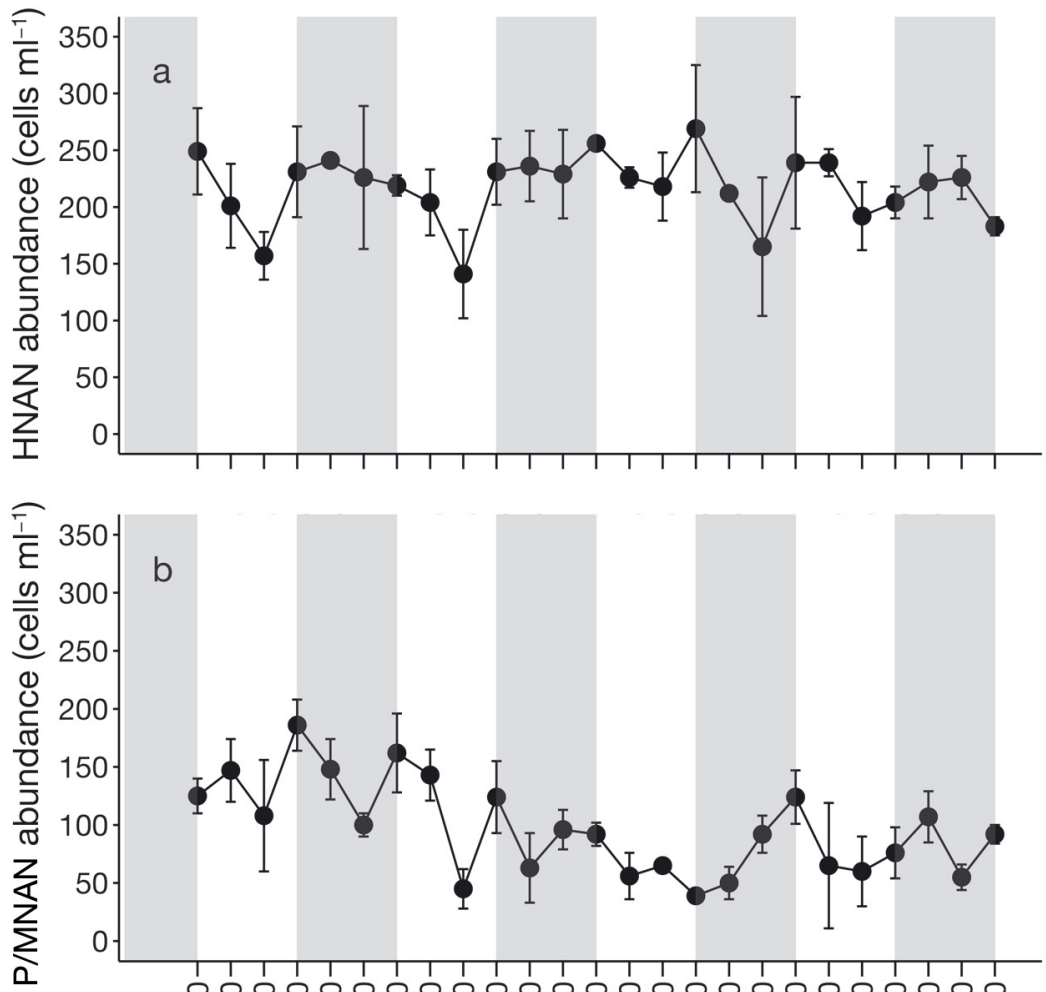

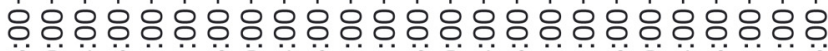

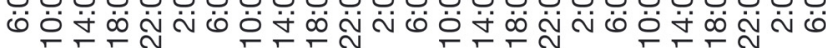

Fig. 2. Abundances of (a) heterotrophic nanoplankton (HNAN) and (b) phototrophic/mixotrophic nanoplankton (P/MNAN) measured at $4 \mathrm{~h}$ time intervals throughout the study period. Nanoplankton abundances were determined from microscope slides made from the $\mathrm{T}_{0}$ time-point of each incubation. Points represent the mean \pm SE measurements at each time-point. Day-night cycles are shown, with gray boxes indicating nighttime. Differences between initial and final abundances of HNAN or initial and final abundances of P/MNAN were not significant (Welch 2-sample $t$-test; $\mathrm{p}=0.19$ and 0.14 , respectively)

blages remained relatively stable throughout the $4 \mathrm{~d}$ period, showing no significant change between the initial and final time-point in the series. Neither the HNAN nor P/MNAN abundances exhibited significant diel periodicity (RAIN analysis, $\mathrm{p}=0.21$ and 0.86, respectively; Fig. 2).

The percentage of TNAN with ingested FLB was $9.9 \pm 0.9 \%$ (Fig. 3a). TNAN ingestion showed significant diel periodicity (RAIN analysis, $\mathrm{p}<0.001$ ) with a peak ingestion time near midnight $(\sim 23: 30 \mathrm{~h})$ and lowest grazing pressure mid-morning ( 10:00 h). Patterns of ingestion for the TNAN were driven largely by the HNAN (which comprised $69 \%$ of the TNAN abundance). The percentage of HNAN with ingested FLB exhibited strong significant diel periodicity (Fig. 3b). The percentage of nanoplankton grazers with ingested FLB was also significantly greater for HNAN $(12 \pm 1.1 \%$; Fig. 3b) than for MNAN (7.9 \pm $0.8 \%$; Fig. 3c). On average, HNAN grazing pressure fluctuated approximately 4.5 -fold within a $24 \mathrm{~h}$ pe- riod, with an average daily minimum of $4.1 \%$ and daily maximum of $18.5 \%$ of grazers observed with ingested FLB. No diel periodicity was detected for MNAN grazing pressure (RAIN analysis, $\mathrm{p}=0.56$ ).

Total cellular biomass of Prochlorococcus and Synechococcus demonstrated significant diel periodicities by RAIN analysis over the $4 \mathrm{~d}$ study period $(\mathrm{p}<$ 0.001; Fig. 4a,b, respectively). Biomass of Prochlorococcus approximately doubled each day during daylight hours and decreased throughout the night, resulting in only modest day-to-day changes in biomass observed during the study period (average increases in biomass of $\sim 5$ and $\sim 3 \%$ for Prochlorococcus and Synechococcus, respectively; Fig. 4). Picocyanobacterial biomass peaked near dusk for both genera and decreased steadily during the night, presumably with losses attributable to a combination of mortality due to grazing, viral lysis, and cell respiration, and reached minima at dawn. Based on daily 


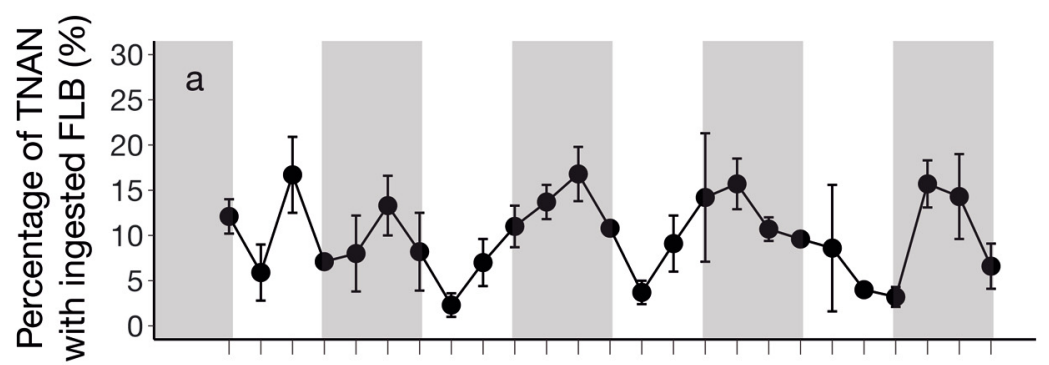

tive but secondary role to HNAN in nanoplanktonic protistan grazing pressure on bacterial-sized particles at this depth and time in the NPSG. MNAN were likely a significant, albeit not dominant, source of grazer-mediated picoplankton mortality, assuming that nanoplankton abundances and percentages of cells with ingested FLB

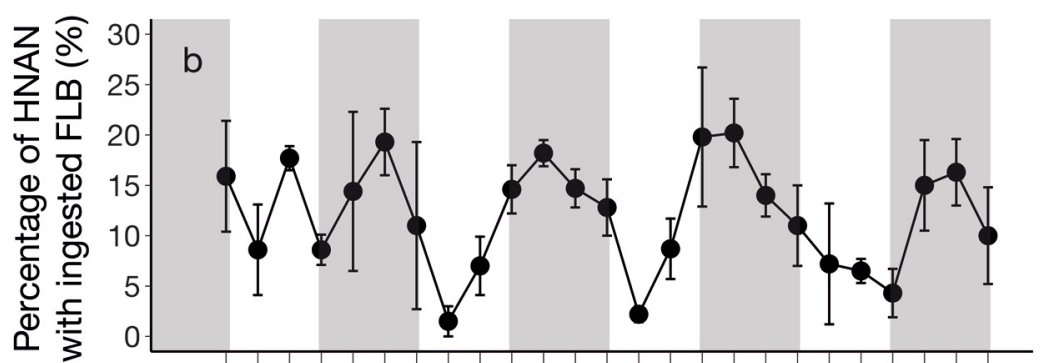
can be extrapolated to ingestion rates. We estimate that MNAN comprised $\sim 25 \%$ of total bacterivory given the average percentage of TNAN constituted by MNAN and the percentages of MNAN and TNAN with ingested FLB (range 5-76\%). HNAN exerted the remaining $75 \%$ of grazing pressure based on similar reasoning.

Recent modeling efforts have indicated that mixotrophic algae may be particularly important bacterivores in oligotrophic ecosystems (Fischer et al. 2017), but nature is not always so straightforward. Some field studies have reported that MNAN constituted $50 \%$ or more of the total bacterivory in equatorial, subtropical, and temperate oceans (Sanders et al. 2000, Unrein et al. 2007, 2014, Zubkov \& Tarran 2008, Stukel et al. 2011, Hartmann et al. 2012); however, the contribution of MNAN to total bacterivory in those studies varied greatly with location, depth, and season (0-90\%). Moreover, studies in polar oceans reported that biomass maxima and minima, estimates of picocyanobacterial biomass losses during the night averaged 3.12 and $0.06 \mu \mathrm{g} \mathrm{Cl}^{-1}$ for Prochlorococcus and Synechococcus, respectively (Fig. S3, Table 1). Interestingly, maxima in the percentages of HNAN with ingested FLB corresponded to periods of decreasing total picocyanobacterial biomass (Fig. 4).

\section{DISCUSSION}

\subsection{Relative contributions of HNAN and MNAN to grazing pressure on cyanobacteria}

Differences in the absolute abundances of HNAN and MNAN (Fig. 2a,b, respectively), and the percentages of these assemblages containing ingested FLB (Fig. 3b,c), imply that MNAN played a substanthe grazing activities of HNAN often outweighed those of MNAN (Sanders \& Gast 2012, Gast et al. 2018).

These differing findings are not surprising given our still-limited knowledge of the importance of grazing by phagotrophic algae in the ocean, the various functions that phagotrophic behavior in MNAN might serve, and our incomplete understanding of the specific environmental factors driving phagotrophy by photosynthetic nanoplankton (Stoecker et al. 2017). Clearly, the taxonomic composition of the mixotrophic assemblage will have an impact on the overall feeding behavior of MNAN. Even closely related mixotrophic algae can exhibit significant differences in feeding behavior in response to light and prey availability (McKie-Krisberg et al. 2015, Lie et al. 2018, Wilken et al. 2020). Predicting their activities is not yet possible, so direct measurements are 

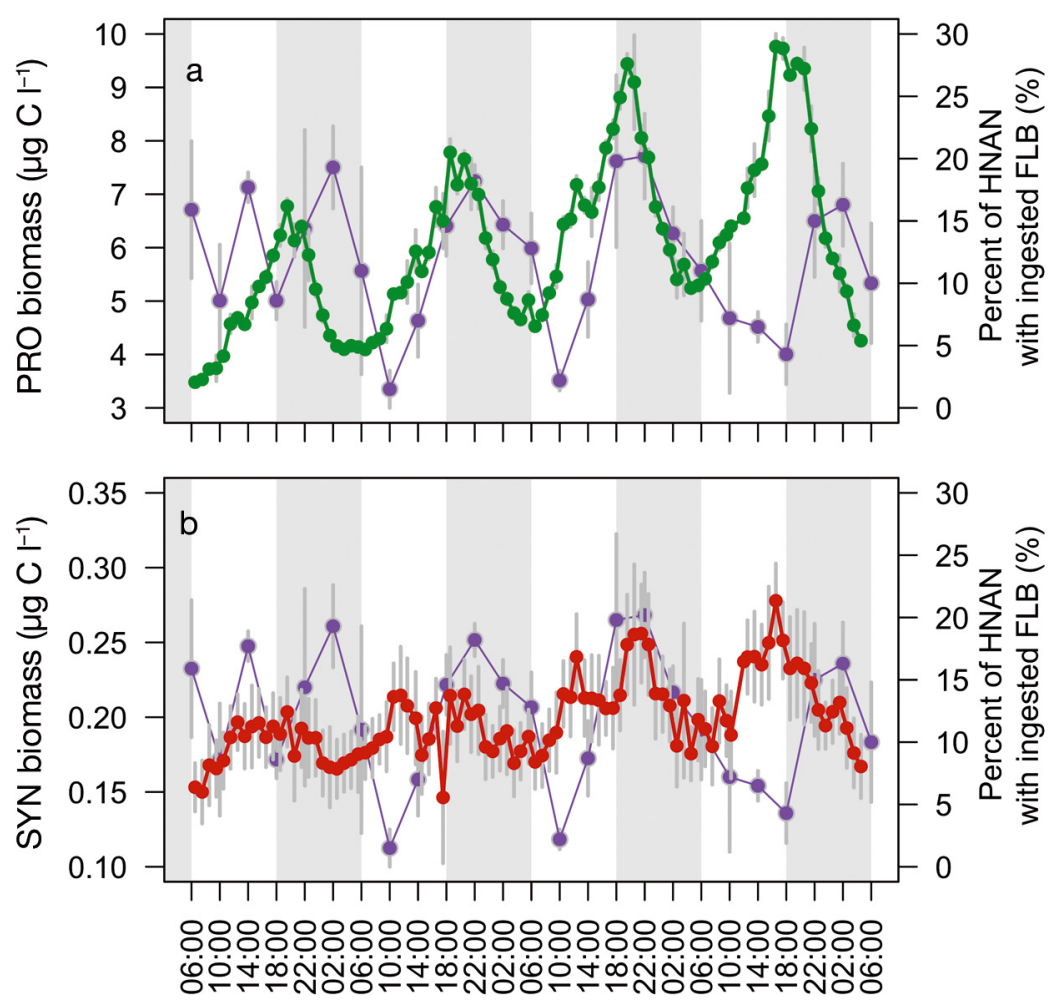

Fig. 4. Biomass of (a) Prochlorococcus (PRO, green) and (b) Synechococcus (SYN, red) throughout the diel cycle, plotted with the percentages of heterotrophic nanoplankton (HNAN, purple) with ingested fluorescently labeled bacteria (FLB) measured at $4 \mathrm{~h}$ time intervals throughout the study period. Day-night cycles are shown, with gray boxes indicating nighttime. The purple lines are the percentages of HNAN with ingested FLB presented in Fig. 3b, and are repeated here to help visualize the temporal relationship between peak in cyanobacterial biomass (peaking at between 18:00-20:00 h), and HNAN grazing activities (peaking at $\sim 23: 30 \mathrm{~h}$ )

necessary. This study, to our knowledge, provides the first estimate of MNAN grazing impact in the NPSG, the largest contiguous biome on the planet (Sverdrup et al. 1942).

The timing of nanoplanktonic grazing activity in this study differed for HNAN and MNAN. HNAN exhibited a pronounced diel periodicity in grazing pressure with a peak at $\sim 23: 30 \mathrm{~h}$ (Fig. 3b), approximately $4 \mathrm{~h}$ after the cyclical peak in cyanobacterial biomass during the evening (daily peaks between 18:00 and 20:00 hi Fig. 4). This peak in Prochlorococcus mortality rates in the NPSG mirrors the timing predicted by models of cyanobacterial mortality based on measurements of cyanobacterial size and abundance obtained using flow cytometry (Ribalet et al. 2015). Conversely, no significant periodicity in grazing pressure was detected for MNAN (Fig. 3c). Grazing pressure by both HNAN and MNAN was lowest mid-morning.
It is possible that the FLB method used in this study specifically underestimated the importance of phagotrophy by MNAN relative to HNAN. The issues and problems associated with understanding and characterizing feeding selectivity by protists are well known (Montagnes et al. 2008, Roberts et al. 2011). The FLB method employed cannot adequately mimic the entire size distribution of natural assemblages of picoplankton-sized prey $(0.2-2.0 \mu \mathrm{m})$, and size selectivity has been shown to be an important factor affecting the suitability of prey to nanoplanktonic consumers (González et al. 1990, Epstein \& Shiaris 1992, Jürgens \& Massana 2008). Other characteristics of Prochlorococcus that might also influence the susceptibility of picocyanobacteria to MNAN vs. HNAN grazers include changes in chemical composition (Siver \& Chock 1986, John \& Davidson 2001, Shannon et al. 2007, Chrzanowski \& Foster 2014, Ng et al. 2017), cell surface properties (Monger et al. 1999, Wootton et al. 2007), the release of infochemicals (Verity 1991, Fenchel \& Blackburn 1999, Breckels et al. 2011), or viral infection (Lawler 1993). Given these caveats of the method, it is probable that some nanoplankton species may have been favored over others in our experimental setup, but there is no a priori reason to assume that these factors would specifically disadvantage MNAN.

These well-known methodological caveats of the FLB method aside, our results raise questions relating to (1) the factors controlling the diel rhythm of HNAN grazing, and (2) why that rhythm was different for HNAN and MNAN. HNAN might increase their grazing activities on cyanobacteria at night because larger prey size or higher abundances increase the probability of encounter with HNAN. Prochlorococcus biomass, in particular, nearly doubled over each diel cycle (Fig. 4a), although day-today changes in biomass were modest $\left(\sim 5 \% \mathrm{~d}^{-1}\right)$. This finding implies that, if HNAN were the major factor removing Prochlorococcus biomass during the night, they were highly attuned to Prochlorococcus dynamics, and responded rapidly to one or both of these factors, resulting in only minor day-to-day changes in prey biomass (successive red dots in Fig. S3). An 
Table 1. Calculations of the daily losses of Prochlorococcus and Synechococcus biomass that might be attributable to nanoplankton grazing. Changes in picocyanobacterial biomass were determined (as described from SeaFlow data) from the maximal values (observed near dusk or early evening) to the minimal values (observed near dawn) in picocyanobacterial biomass (see zenith and nadir values indicated in Fig. S3). We assumed that $20 \%$ of the carbon was lost to respiration. The carbon biomass remaining was then used to estimate the potential picocyanobacterial carbon contribution to nanoplankton diet, assuming that grazers in the nanoplankton size class are the major source of picocyanobacterial mortality

\begin{tabular}{|c|c|c|c|}
\hline $\begin{array}{l}\text { Date in } 2015 \\
\text { (mo/d) }\end{array}$ & $\begin{array}{l}\text { Point on } \\
\text { curve }\end{array}$ & $\begin{array}{l}\text { Biomass } \\
\left(\mu \mathrm{C} \mathrm{C}^{-1}\right)\end{array}$ & $\begin{array}{c}\text { Biomass } \\
\text { removal } \\
\left(\mu g \mathrm{C}^{-1}\right)\end{array}$ \\
\hline \multicolumn{4}{|c|}{ Prochlorococcus } \\
\hline $7 / 26-7 / 27$ & $\begin{array}{l}\text { Zenith } \\
\text { Nadir }\end{array}$ & $\begin{array}{l}6.78 \\
4.09\end{array}$ & 2.15 \\
\hline $7 / 27-7 / 28$ & $\begin{array}{l}\text { Zenith } \\
\text { Nadir }\end{array}$ & $\begin{array}{l}7.78 \\
4.52\end{array}$ & 2.61 \\
\hline $7 / 28-7 / 29$ & $\begin{array}{l}\text { Zenith } \\
\text { Nadir }\end{array}$ & $\begin{array}{l}9.44 \\
5.24\end{array}$ & 3.36 \\
\hline $7 / 29-7 / 30$ & $\begin{array}{l}\text { Zenith } \\
\text { Nadir }\end{array}$ & $\begin{array}{l}9.73 \\
4.26\end{array}$ & 4.38 \\
\hline Synechococc & & & \\
\hline $7 / 26-7 / 27$ & $\begin{array}{l}\text { Zenith } \\
\text { Nadir }\end{array}$ & $\begin{array}{l}0.20 \\
0.17\end{array}$ & 0.02 \\
\hline $7 / 27-7 / 28$ & $\begin{array}{l}\text { Zenith } \\
\text { Nadir }\end{array}$ & $\begin{array}{l}0.25 \\
0.17\end{array}$ & 0.06 \\
\hline $7 / 28-7 / 29$ & $\begin{array}{l}\text { Zenith } \\
\text { Nadir }\end{array}$ & $\begin{array}{l}0.26 \\
0.18\end{array}$ & 0.06 \\
\hline $7 / 29-7 / 30$ & $\begin{array}{l}\text { Zenith } \\
\text { Nadir }\end{array}$ & $\begin{array}{l}0.28 \\
0.16\end{array}$ & 0.10 \\
\hline
\end{tabular}

alternative or perhaps additive possibility is that chemical composition of Prochlorococcus varied over the diel cycle, eliciting greater grazing pressure specifically by HNAN during the night. Regardless of the underlying mechanism, the diel variability in HNAN grazing pressure observed in this study reveals a complexity of grazing behavior that extends beyond the standard formulations of grazing being solely a function of prey abundance as described in many ecosystem models, and is therefore a topic requiring further study.

\subsection{Differences in the timing of HNAN and MNAN ingestion may reflect varying nutritional needs}

We speculate that the observed diel periodicity of grazing by HNAN versus the relative aperiodicity of MNAN grazing may reflect differences in the nutritional needs provided by prey ingestion. Hetero- trophic protistan grazers phagocytize prey to fulfill all their nutritional needs (carbon, macro- and micronutrients, energy). Maximizing ingestion rates at the time of the daily peak of prey abundance and biomass of cyanobacterial prey (Fig. 4) may act to most efficiently fulfill those requirements. As noted immediately above, however, the exact mechanism by which HNAN synchronize the timing of their maximal feeding activity with the peak of Prochlorococcus abundance and/or biomass (Fig. 4) is unknown.

In contrast to phagotrophy in HNAN, which must fulfill all nutritional requirements of the cells, phagotrophy by nanoplanktonic algae (MNAN) may supply a range of specific nutritional needs, i.e. carbon or energy (Terrado et al. 2017), macronutrients (Nygaard \& Tobiesen 1993, Arenovski et al. 1995, Unrein et al. 2007, Hartmann et al. 2011), or micronutrients (Maranger et al. 1998, Stukel et al. 2011). The specific requirements of mixotrophs that are met by phagotrophy vary among species (Liu et al. 2016, Stoecker et al. 2017). It is probable that cellular requirements for macronutrients (e.g. nitrogen, phosphorus) and particularly for micronutrients (e.g. iron, vitamins) might be met in MNAN by modest, relatively constant rates of prey ingestion throughout the day, while other materials (e.g. carbon) might be largely acquired via photosynthesis during the light period. The lack of diel periodicity in MNAN grazing pressure, in combination with the persistently nutrient-deplete conditions found in the NPSG (Karl \& Church 2014), suggest that MNAN in this environment may be ingesting prey primarily as a means of nutrient acquisition rather than for meeting carbon or energy requirements. Phagotrophy by MNAN as a strategy for acquiring nutrients is in agreement with a recent ecosystem model suggesting that mixotrophy could be an important nutrient acquisition strategy for phototrophic nanoplankton to survive in subtropical gyres (Ward \& Follows 2016). However, our results are not proof of this strategy, and we cannot exclude the possibility that different species of MNAN exhibited diel cycles with different phases and/or amplitudes, blurring an overall periodicity for MNAN grazing pressure.

\subsection{Protistan grazing may contribute to day-to-day stability of picocyanobacterial populations}

Estimated carbon biomass of the 2 picocyanobacterial assemblages at the sampling location peaked around dusk during this study (Fig. 4), particularly for 
Prochlorococcus, which strongly dominated the picocyanobacteria (Fig. 4a) as has been previously observed (Binder \& DuRand 2002). Despite the approximate doubling of Prochlorococcus biomass over the diel cycle, day-to-day changes were minor (only 5\% $\mathrm{d}^{-1}$ averaged over the $4 \mathrm{~d}$ study), indicating a tight coupling between prey availability and cell mortality from grazing and/or viral lysis. Decreases in cyanobacterial biomass due to nighttime respiration or carbon purging (Ribalet et al. 2015, Lopez et al. 2016) are expected to be minor relative to mortality.

The feasibility of nanoplankton consumers to constrain picocyanobacterial population increases to the observed modest day-to-day changes were assessed by estimating the predation pressure that would be necessary to maintain constant Prochlorococcus and Synechococcus biomass. These were speculative estimations that place bounds on the potential of phagotrophic nanoplankton to play a key role in controlling cyanobacterial abundances in the NPSG. Given recent studies that the mortality of Prochlorococcus attributable to viral lysis is minor in this ecosystem (Mruwat et al. 2020), trophic activities by grazers would appear to be a major source of mortality. Assuming that $20 \%$ of the carbon fixed by picocyanobacteria was respired at night (Ribalet et al. 2015, Lopez et al. 2016), diel changes in the biomass of these assemblages indicated that an average of $3.12 \mu \mathrm{g} \mathrm{C}^{-1}$ of Prochlorococcus biomass (range of 2.15-4.38 $\mu \mathrm{g} \mathrm{Cl}^{-1}$ over the study period) and an average of $0.06 \mu \mathrm{g} \mathrm{Cl}^{-1}$ of Synechococcus biomass (range of $0.02-0.10 \mu \mathrm{g} \mathrm{C} \mathrm{I}^{-1}$ ) were removed daily (Table 1 , Fig. S3). The numbers of picocyanobacterial cells constituted by these biomass values were estimated using conversion factors of $38 \mathrm{fg} \mathrm{C}^{\mathrm{C}}$ cell $^{-1}$ for Prochlorococcus and $233 \mathrm{fg} \mathrm{C}$ cell $^{-1}$ for Synechococcus (as noted in Section 2). Averaged over our $4 \mathrm{~d}$ study period, $8.2 \times 10^{4}$ Prochlorococcus cells ml ${ }^{-1}$ and $2.7 \times$ $10^{2}$ Synechococcus cells ml ${ }^{-1}$ were removed each day. Using a mean nanoplankton abundance of 313 cells $\mathrm{ml}^{-1}$ (the sum of values in Fig. 2a,b) and assuming that nanoplankton grazed only picocyanobacteria, we estimate that maintaining constant day-to-day picocyanobacterial stock would require the consumption of only $\sim 260$ Prochlorococcus cells nanoplankter ${ }^{-1} \mathrm{~d}^{-1}$, and $<1$ Synechococcus nanoplankter ${ }^{-1} \mathrm{~d}^{-1}$.

Complete removal of daily cyanobacterial production by nanoplanktonic protists during our study was therefore feasible, although not proven. Ingestion rates reported for nanoplanktonic consumers are much higher and typically range from tens to hundreds of picoplanktonic prey $\mathrm{h}^{-1}$ (Fenchel 1986, Nygaard \& Tobiesen 1993, Sherr \& Sherr 2002). Val- ues at the low end of this range would be expected because abundances of cyanobacteria in the NPSG are 1 to 2 orders of magnitude lower that those typically employed in experiments investigating protistan ingestion rates in laboratory cultures. It is also likely that prey abundances in the NPSG are close to the grazing thresholds for phagotrophic nanoplankton in oceanic waters, implying that nanoplankton may be able to remove daily production, but cannot effectively reduce prey abundances below those thresholds (Caron 1990).

Diel periodicity in the timing of cell division of Prochlorococcus might require more intense predation by nanoplankton at dusk and into the evening in order to prevent increases in picocyanobacterial abundance (Ribalet et al. 2015), but increases in the rates of predation by nanoplankton would not need to be large to keep pace with prey cell division. Interestingly, the measured hourly percentages of HNAN with ingested FLB were 4.5 times higher during the night relative to percentages measured during the day (Figs. 3b \& 4). Increased predation rates on dividing picocyanobacteria at night might also contribute to efficient removal of prey biomass, although the specific mechanisms by which dividing cells would be targeted (e.g. larger cell size, changes in cellular composition) remain undetermined.

Viral lysis is another potential source of picocyanobacterial mortality, but as noted above, viral infection rates were modest during the study period (Mruwat et al. 2020). However, a transcriptomic analysis conducted concurrently with the present study indicated that viral gene transcription was synchronized to Prochlorococcus DNA replication during the afternoon in the NPSG (Aylward et al. 2017). A diel cycle of viral infection late in the day, together with increased grazing pressure from HNAN at night, might easily constrain Prochlorococcus to the modest day-to-day net increases in biomass observed in this study. It is even conceivable that virally infected cyanobacterial cells were more susceptible to consumption by grazers (Evans \& Wilson 2008, Zwirglmaier et al. 2009), perhaps explaining the higher percentages of HNAN with ingested FLB that we observed at night.

\subsection{Contribution of bacterial carbon to nanoplankton growth}

Measurements of the daily removal of cyanobacterial biomass were used to calculate the carbon potentially available for nanoplankton consuming 
that biomass in the NPSG. Again, these were speculative calculations to estimate the potential contribution of prey biomass to nanoplankton nutrition. The average daily removal was $3.12 \mu \mathrm{g} \mathrm{C} \mathrm{l}^{-1}$ for Prochlorococcus and $0.06 \mu \mathrm{g} \mathrm{C} \mathrm{l}^{-1}$ for Synechococcus (Table 1). A loss of $20 \%$ carbon to cyanobacterial respiration was assumed. Losses to viral lysis were not considered. One conclusion from these calculations is that Synechococcus comprised a small portion of the total nanoplankton diet relative to Prochlorococcus and likely had little impact on the nutrition of the phagotrophic nanoplankton assemblage during the study.

Carbon demand for growth of the phagotrophic nanoplankton assemblage was calculated according to:

$$
\left[\left(\mu \times \mathrm{B}_{\mathrm{v}} \times \mathrm{C}\right) / \mathrm{GGE}\right] \times \mathrm{NAN}
$$

where $\mu$ = nanoplankton growth rate $\left(\mathrm{d}^{-1}\right), \mathrm{B}_{\mathrm{v}}=$ nano-

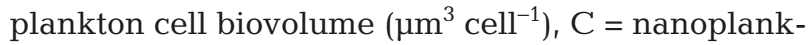
ton carbon content $\left(\mu \mathrm{g} \mathrm{C}_{\mu \mathrm{m}^{-3}}\right), \mathrm{GGE}=$ nanoplankton gross growth efficiency, and NAN = nanoplankton abundance (average $=313 \mathrm{cells} \mathrm{ml}^{-1}$ ). Using the calculated removal of Prochlorococcus carbon $(3.12 \mu \mathrm{g}$ $\mathrm{C}^{-1} \mathrm{~d}^{-1}$ ) corrected for respiratory losses, a carbon

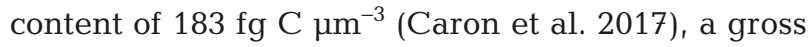
growth efficiency of $30 \%$ (Straile 1997), and a range of nanoplankton diameters $(3-6 \mu \mathrm{m})$, we estimate that the Prochlorococcus biomass removed daily could have supported nanoplankton growth rates of 0.14 to $1.2 \mathrm{~d}^{-1}$ (for the range of nanoplankton cell sizes considered), a finding that is very consistent with nanoplankton growth rates reported from field studies (0.2 to $\sim 1.4 \mathrm{~d}^{-1}$ ) (Verity et al. 1993, Neuer \& Cowles 1994, Karayanni et al. 2008). Thus, it appears that the nighttime decreases in cyanobacterial biomass could support considerable growth of the nanoplankton community if they were the primary consumers of that biomass.

Heterotrophic bacterioplankton (bacteria + archaea) within the picoplankton size class $(0.2-2.0 \mu \mathrm{m})$ are another important source of prey for phagotrophic protists in the nanoplankton size class $(2-20 \mu \mathrm{m})$. The mean abundance of heterotrophic bacterioplankton at Stn ALOHA has been reported to be $\sim 5.5 \times 10^{5}$ cells $\mathrm{ml}^{-1}$ in the upper $125 \mathrm{~m}$ (Eiler et al. 2009), which equates to $5.5 \mathrm{\mu g} \mathrm{Cl}^{-1}$ of heterotrophic bacterioplankton biomass using a carbon conversion factor of $10 \mathrm{fg}$ $\mathrm{C} \mathrm{cell}^{-1}$ that is representative of open-ocean environments (Fukuda et al. 1998, Kawasaki et al. 2011, Cermak et al. 2017). Assuming a mean growth rate of $0.08 \mathrm{~d}^{-1}$ for open-ocean bacterioplankton (Kirchman 2016), the production of heterotrophic bacterial car- bon at Stn ALOHA would be $0.44 \mu \mathrm{g} \mathrm{Cl}^{-1} \mathrm{~d}^{-1}$. Thus, the estimated production of heterotrophic bacterial carbon was approximately one-seventh the observed production of cyanobacterial carbon $\left(3.12 \mu \mathrm{g} \mathrm{Cl}^{-1} \mathrm{~d}^{-1}\right.$, see above), and by itself would have supported nanoplankton growth rates in the range $0.0-0.16 \mathrm{~d}^{-1}$ for the size range of nanoplankton considered here. Therefore, we conclude that Prochlorococcus production by itself was capable of supporting realistic protistan growth rates in the NPSG during our study if they were the primary source of cyanobacterial mortality.

\subsection{Impact of grazing periodicity on other microbial assemblages}

Protistan grazers are the primary sources of nutrients and dissolved organic matter for the phytoplankton and bacterial communities (Caron \& Goldman 1990), and they are important prey items for mesozooplankton (Stoecker \& Capuzzo 1990, Brum et al. 2014). Thus, the diel periodicity in HNAN grazing pressure observed during our study suggests that grazer excretion of dissolved organic matter (DOM) may also be cyclical. In accordance with this prediction, heterotrophic bacteria have been shown to undergo a coordinated upregulation of transcripts related to oxidative phosphorylation, metabolite transport, peptidases, amino acid metabolism, and the citric acid cycle in the afternoon in the NPSG, suggesting that they are responding to daily pulses of DOM (Aylward et al. 2015). Protistan grazers are thought to be a major source of DOM production in oligotrophic ocean regimes due to the tight coupling between predator and prey populations as described in this study, although phytoplankton release of excess fixed carbon late in the light period each day may also be an important source of DOM when nutrients are limiting (Nagata 2000). A combination of rhythmic cycles of phytoplankton exudation and grazer excretion of DOM is consistent with the upregulation of bacterial metabolic transcripts in the afternoon observed by Aylward et al. (2015).

Interestingly, HNAN abundances did not show significant diel periodicity and remained unchanged throughout the $4 \mathrm{~d}$ study period. That constancy presumably indicates a tight coupling between cycles of nanoplankton production and grazing by higher trophic levels (micro- or mesozooplankton), given that estimated nanoplankton doubling times were substantial (see growth rates in Section 4.4). Culture studies of microzooplankton grazing on nanoplankton suggest that grazing by some species is higher 
during the day; however, results vary between species (Jakobsen \& Strom 2004, Ng et al. 2017). A significant number of mesozooplankton taxa vertically migrate at night to feed in the surface waters at Stn ALOHA, with an average nighttime zooplankton biomass increase of $\sim 40 \%$ in the euphotic zone (AlMutairi \& Landry 2001). Thus, it is possible that mesozooplankton were migrating to the euphotic zone at night, consuming nanoplankton production, and contributing to the stable nanoplankton population abundances observed during our study. Quantifying the relative importance of microzooplankton and mesozooplankton to heterotrophic nanoplankton mortality, as well as the level of synchrony between the activities of these populations, will provide greater insight into the extent to which the diel cycle impacts biogeochemical fluxes in marine environments.

\section{CONCLUSION}

Our findings in this study are consistent with a tightly coordinated transfer of energy from picocyanobacterial primary producers to their microbial consumers that recurred daily at our NPSG study site. The specific environmental and/or biological factors controlling this relationship are unclear. Yet, the observed coupling between the cyanobacterial and nanoplanktonic assemblages has implications for the timing and nature of the movement of elements and energy through the ecosystem, and should be considered when choosing methods for making measurements of trophic interactions within microbial food webs. We observed peaks in marine picocyanobacterial biomass at dusk that were consistently followed by peaks in nanoplankton grazing pressure 4-5 h later. Estimates of daily prey carbon removal and nanoplankton community carbon demand for growth suggest that protistan grazers may obtain considerable nutrition by consuming picocyanobacteria, and contribute to the remarkable day-to-day stability of picocyanobacterial populations in the NPSG (Ribalet et al. 2015). A strong diel cycle in grazing was observed for the heterotrophic nanoplankton, which are solely dependent on prey carbon to meet their nutritional needs, but not for the mixotrophic nanoplankton. Our results are consistent with recent speculation that oceanic mixotrophic algae consume prey continuously, albeit at relatively slow rates, primarily to alleviate nutrient limitation. This study demonstrates the complexity of predatorprey relationships in marine food webs and emphasizes the importance of quantifying grazer commu- nity composition and nutritional requirements when assessing the nature and timing of biogeochemical fluxes in the marine environment.

Acknowledgements. This work was generously funded by the Simons Foundation, as part of the Simons Collaboration on Ocean Processes and Ecology (SCOPE) (grant number P49802 to D.A.C.). We thank the captain and crew of the RV 'Kilo Moana' as well as the SCOPE Operations Team for facilitating back-deck operations and field incubations. We are grateful to Sam Wilson for serving as Chief Scientist on this cruise and ensuring that the diel sampling proceeded seamlessly. We acknowledge Benedetto Barone and Sam Wilson for providing the eddy altimetry map which is included as part of Fig. 1. In addition, we thank Frank Aylward for providing custom $\mathrm{R}$ script to conduct harmonic regression analysis, and Evelyn Lessard (University of Washington) for providing the strain NPEC29 to F.R.

\section{LITERATURE CITED}

Ahlgren NA, Rocap G (2012) Diversity and distribution of marine Synechococcus: multiple gene phylogenies for consensus classification and development of qPCR assays for sensitive measurement of clades in the ocean. Front Microbiol 3:213

Al-Mutairi H, Landry MR (2001) Active export of carbon and nitrogen at Station ALOHA by diel migrant zooplankton. Deep Sea Res II 48:2083-2103

Anderson R, Jürgens K, Hansen PJ (2017) Mixotrophic phytoflagellate bacterivory field measurements strongly biased by standard approaches: a case study. Front Microbiol 8:1398

Arenovski AL, Lim EL, Caron DA (1995) Mixotrophic nanoplankton in oligotrophic surface waters of the Sargasso Sea may employ phagotrophy to obtain major nutrients. J Plankton Res 17:801-820

Aylward FO, Eppley JM, Smith JM, Chavez FP, Scholin CA, DeLong EF (2015) Microbial community transcriptional networks are conserved in three domains at ocean basin scales. Proc Natl Acad Sci USA 112:5443-5448

* Aylward FO, Boeuf D, Mende DR, Wood-Charlson EM and others (2017) Diel cycling and long-term persistence of viruses in the ocean's euphotic zone. Proc Natl Acad Sci USA 114:11446-11451

* Barone B, Bidigare RR, Church MJ, Karl DM, Letelier RM, White AE (2015) Particle distributions and dynamics in the euphotic zone of the North Pacific Subtropical Gyre. J Geophys Res 120:3229-3247

* Biller SJ, Berube PM, Lindell D, Chisholm SW (2015) Prochlorococcus: the structure and function of collective diversity. Nat Rev Microbiol 13:13-27

*Binder BJ, DuRand MD (2002) Diel cycles in surface waters of the equatorial Pacific. Deep Sea Res II 49:2601-2617

* Breckels MN, Roberts EC, Archer SD, Malin G, Steinke M (2011) The role of dissolved infochemicals in mediating predator-prey interactions in the heterotrophic dinoflagellate Oxyrrhis marina. J Plankton Res 33:629-639

Brum JR, Morris JJ, Décima M, Stukel MR (2014) Mortality in the oceans: causes and consequences. In: Kemp PF (ed) Proc Eco-DAS IX. Association for the Sciences of Limnology and Oceanography, Waco, TX 
Calbet A, Landry MR (1999) Mesozooplankton influences on the microbial food web: direct and indirect trophic interactions in the oligotrophic open ocean. Limnol Oceanogr 44:1370-1380

Calbet A, Landry MR (2004) Phytoplankton growth, microzooplankton grazing, and carbon cycling in marine systems. Limnol Oceanogr 49:51-57

Caron DA (1990) Growth of two species of bacterivorous nanoflagellates in batch and continuous culture, and implications for their planktonic existence. Mar Microb Food Webs 4:143-159

Caron DA (2000) Protistan herbivory and bacterivory. In: Paul $\mathrm{J}$ (ed) Marine microbiology: methods in microbiology, Book 30. Academic Press, San Diego, CA, p 289-315

Caron DA, Goldman JC (1990) Protozoan nutrient regeneration. In: Capriulo GM (ed) Ecology of marine protozoa. Oxford University Press, New York, NY, p 283-306

* Caron DA, Connell PE, Schaffner RA, Schnetzer A, Fuhrman JA, Countway PD, Kim DY (2017) Planktonic food web structure at a coastal time-series site: I. Partitioning of microbial abundances and carbon biomass. Deep Sea Res I 121:14-29

* Casey JR, Aucan JP, Goldberg SR, Lomas MW (2013) Changes in partitioning of carbon amongst photosynthetic pico- and nano-plankton groups in the Sargasso Sea in response to changes in the North Atlantic Oscillation. Deep Sea Res II 93:58-70

* Cermak N, Becker JW, Knudsen SM, Chisholm SW, Manalis SR, Polz MF (2017) Direct single-cell biomass estimates for marine bacteria via Archimedes' principle. ISME J 11: 825-828

* Christaki U, Courties C, Karayanni H, Giannakourou A, Maravelias C, Kormas KA, Lebaron P (2002) Dynamic characteristics of Prochlorococcus and Synechococcus consumption by bacterivorous nanoflagellates. Microb Ecol 43:341-352

* Chrzanowski TH, Foster BLL (2014) Prey element stoichiometry controls ecological fitness of the flagellate Ochromonas danica. Aquat Microb Ecol 71:257-269

* Connell PE, Campbell V, Gellene AG, Hu SK, Caron DA (2017) Planktonic food web structure at a coastal timeseries site: II. Spatiotemporal variability of microbial trophic activities. Deep Sea Res I 121:210-223

Connell PE, Michel C, Meisterhans G, Arrigo KR, Caron DA (2018) Phytoplankton and bacterial dynamics on the Chukchi Sea Shelf during the spring-summer transition. Mar Ecol Prog Ser 602:49-62

* Deng L, Cheung S, Liu H (2020) Protistal grazers increase grazing on unicellular cyanobacteria diazotroph at night. Front Mar Sci 7:135

Dolan JR, Šimek K (1999) Diel periodicity in Synechococcus and grazing by heterotrophic nanoflagellates: analysis of food vacuole contents. Limnol Oceanogr 44:1565-1570

Dufresne A, Garczarek L, Partensky F (2005) Accelerated evolution associated with genome reduction in a freeliving prokaryote. Genome Biol 6:R14

Eiler A, Hayakawa DH, Church MJ, Karl DM, Rappé MS (2009) Dynamics of the SAR11 bacterioplankton lineage in relation to environmental conditions in the oligotrophic North Pacific Subtropical Gyre. Environ Microbiol 11:2291-2300

Epstein SS, Shiaris MP (1992) Size-selective grazing of coastal bacterioplankton by natural assemblages of pigmented flagellates, colorless flagellates, and ciliates. Microb Ecol 23:211-225
Evans C, Wilson WH (2008) Preferential grazing of Oxyrrhis marina on virus infected Emiliania huxleyi. Limnol Oceanogr 53:2035-2040

Fenchel T (1986) The ecology of heterotrophic microflagellates. Adv Microb Ecol 9:57-97

Fenchel T, Blackburn N (1999) Motile chemosensory behaviour of phagotrophic protists: mechanisms for and efficiency in congregating at food patches. Protist 150: 325-336

* Field CB, Behrenfeld MJ, Randerson JT, Falkowski P (1998) Primary production of the biosphere: integrating terrestrial and oceanic components. Science 281:237-240

Fischer R, Giebel HA, Hillebrand H, Ptacnik R (2017) Importance of mixotrophic bacterivory can be predicted by light and loss rates. Oikos 126:713-722

Flombaum P, Gallegos JL, Gordillo RA, Rincón J and others (2013) Present and future global distributions of the marine cyanobacteria Prochlorococcus and Synechococcus. Proc Natl Acad Sci USA 110:9824-9829

* Fukuda R, Ogawa H, Nagata T, Koike I (1998) Direct determination of carbon and nitrogen contents of natural bacterial assemblages in marine environments. Appl Environ Microbiol 64:3352-3358

Gast RJ, Fay SA, Sanders RW (2018) Mixotrophic activity and diversity of Antarctic marine protists in austral summer. Front Mar Sci 5:13

* González JM, Sherr EB, Sherr BF (1990) Size-selective grazing on bacteria by natural assemblages of estuarine flagellates and ciliates. Appl Environ Microbiol 56:583-589

* Hartmann M, Grob C, Scanlan DJ, Martin AP, Burkill PH, Zubkov MV (2011) Comparison of phosphate uptake rates by the smallest plastidic and aplastidic protists in the North Atlantic subtropical gyre. FEMS Microbiol Ecol 78:327-335

* Hartmann M, Grob C, Tarran GA, Martin AP, Burkill PH, Scanlan DJ, Zubkov MV (2012) Mixotrophic basis of Atlantic oligotrophic ecosystems. Proc Natl Acad Sci USA 109:5756-5760

Jakobsen HH, Strom SL (2004) Circadian cycles in growth and feeding rates of heterotrophic protist plankton. Limnol Oceanogr 49:1915-1922

John EH, Davidson K (2001) Prey selectivity and the influence of prey carbon:nitrogen ratio on microflagellate grazing. J Exp Mar Biol Ecol 260:93-111

Jürgens K, Massana R (2008) Protistan grazing on marine bacterioplankton. In: Kirchman DL (ed) Microbial ecology of the oceans. John Wiley \& Sons, Hoboken, NJ, p 383-442

Karayanni H, Christaki U, Van Wambeke F, Thyssen M, Denis M (2008) Heterotrophic nanoflagellate and ciliate bacterivorous activity and growth in the northeast Atlantic Ocean: a seasonal mesoscale study. Aquat Microb Ecol 51:169-181

*Karl DM, Church MJ (2014) Microbial oceanography and the Hawaii Ocean Time-series programme. Nat Rev Microbiol 12:699-713

Kawasaki N, Sohrin R, Ogawa H, Nagata T, Benner R (2011) Bacterial carbon content and the living and detrital bacterial contributions to suspended particulate organic carbon in the North Pacific Ocean. Aquat Microb Ecol 62:165-176

Kirchman DL (2016) Growth rates of microbes in the oceans. Annu Rev Mar Sci 8:285-309

*Landry MR, Calbet A (2004) Microzooplankton production in the oceans. ICES J Mar Sci 61:501-507 
Lawler SP (1993) Direct and indirect effects in microcosm communities of protists. Oecologia 93:184-190

Lie AAY, Liu Z, Terrado R, Tatters AO, Heidelberg KB, Caron DA (2018) A tale of two mixotrophic chrysophytes: insights into the metabolisms of two Ochromonas species (Chrysophyceae) through a comparison of gene expression. PLOS ONE 13:e0192439

Liu Z, Campbell V, Heidelberg KB, Caron DA (2016) Gene expression characterizes different nutritional strategies among three mixotrophic protists. FEMS Microbiol Ecol 92:fiw106

Lopez JS, Garcia NS, Talmy D, Martiny AC (2016) Diel variability in the elemental composition of the marine cyanobacterium Synechococcus. J Plankton Res 38:1052-1061

Mann EL, Ahlgren NA, Moffett JW, Chisholm SW (2002) Copper toxicity and cyanobacteria ecology in the Sargasso Sea. Limnol Oceanogr 47:976-988

Maranger R, Bird DF, Price NM (1998) Iron acquisition by photosynthetic marine phytoplankton from ingested bacteria. Nature 396:248-251

Massana R, Unrein F, Rodríguez-Martínez R, Forn I, Lefort T, Pinhassi J, Not F (2009) Grazing rates and functional diversity of uncultured heterotrophic flagellates. ISME J 3:588-596

McKie-Krisberg ZM, Gast RJ, Sanders RW (2015) Physiological responses of three species of Antarctic mixotrophic phytoflagellates to changes in light and dissolved nutrients. Microb Ecol 70:21-29

Monger BC, Landry MR, Brown SL (1999) Feeding selection of heterotrophic marine nanoflagellates based on the surface hydrophobicity of their picoplankton prey. Limnol Oceanogr 44:1917-1927

Montagnes DJS, Barbosa AB, Boenigk J, Davidson K and others (2008) Selective feeding behaviour of key freeliving protists: avenues for continued study. Aquat Microb Ecol 53:83-98

Mruwat N, Carlson MCG, Goldin S, Ribalet F and others (2020) A single-cell polony method reveals low levels of infected Prochlorococcus despite high cyanophage abundances in oligotrophic waters. ISME J (in press) doi: 10.1038/s41396-020-00752-6

Nagata T (2000) Production mechanisms of dissolved organic matter. In: Kirchman DL (ed) Microbial ecology of the oceans. John Wiley \& Sons, New York, NY, p 121-152

Neuer S, Cowles TJ (1994) Protist herbivory in the Oregon upwelling system. Mar Ecol Prog Ser 113:147-162

Ng WHA, Liu H (2016) Diel periodicity of grazing by heterotrophic nanoflagellates influenced by prey cell properties and intrinsic grazing rhythm. J Plankton Res 38: 636-651

Ng WHA, Liu H, Zhang S (2017) Diel variation of grazing of the dinoflagellate Lepidodinium sp. and ciliate Euplotes sp. on algal prey: the effect of prey cell properties. J Plankton Res 39:450-462

* Nygaard K, Tobiesen A (1993) Bacterivory in algae: a survival strategy during nutrient limitation. Limnol Oceanogr 38: 273-279

Partensky F, Hess WR, Vaulot D (1999) Prochlorococcus, a marine photosynthetic prokaryote of global significance. Microbiol Mol Biol Rev 63:106-127

Pittera J, Humily F, Thorel M, Grulois D, Garczarek L, Six C (2014) Connecting thermal physiology and latitudinal niche partitioning in marine Synechococcus. ISME J 8: 1221-1236
R Development Core Team (2015) R: a language and environment for statistical computing. R Foundation for Statistical Computing, Vienna

Ribalet F, Swalwell J, Clayton S, Jiménez V and others (2015) Light-driven synchrony of Prochlorococcus growth and mortality in the subtropical Pacific gyre. Proc Natl Acad Sci USA 112:8008-8012

* Ribalet F, Berthiaume C, Hynes A, Swalwell J and others (2019) SeaFlow data v1, high-resolution abundance, size and biomass of small phytoplankton in the North Pacific. Sci Data 6:277

* Roberts EC, Legrand C, Steinke M, Wootton EC (2011) Mechanisms underlying chemical interactions between predatory planktonic protists and their prey. J Plankton Res 33:833-841

* Sanders RW, Gast RJ (2012) Bacterivory by phototrophic picoplankton and nanoplankton in Arctic waters. FEMS Microbiol Ecol 82:242-253

Sanders RW, Berninger UG, Lim EL, Kemp PF, Caron DA (2000) Heterotrophic and mixotrophic nanoplankton predation on picoplankton in the Sargasso Sea and on Georges Bank. Mar Ecol Prog Ser 192:103-118

Schnetzer A, Caron DA (2005) Copepod grazing impact on the trophic structure of the microbial assemblage of the San Pedro Channel, California. J Plankton Res 27: 959-971

* Shannon SP, Chrzanowski TH, Grover JP (2007) Prey food quality affects flagellate ingestion rates. Microb Ecol 53: $66-73$

Sherr BF, Sherr EB, Fallon RD (1987) Use of monodispersed, fluorescently labeled bacteria to estimate in situ protozoan bacterivory. Appl Environ Microbiol 53:958-965

Sherr EB, Sherr BF (2002) Significance of predation by protists in aquatic microbial food webs. Ant Leeuwenhoek 81:293-308

Sherr EB, Caron DA, Sherr BF (1993) Staining of heterotrophic protists for visualization via epifluorescence microscopy. In: Kemp P, Sherr B, Sherr E, Cole J (eds) Handbook of methods in aquatic microbial ecology. Lewis Publishers, Boca Raton, FL, p 213-227

Siver PA, Chock JS (1986) Phytoplankton dynamics in a chrysophysean lake. In: Kritiansen J, Andersen RA (eds) Chrysophytes: aspects and problems. Cambridge University Press, Cambridge, p 165-183

* Stoecker DK, Capuzzo JM (1990) Predation on protozoa: its importance to zooplankton. J Plankton Res 12:891-908

* Stoecker DK, Hansen PJ, Caron DA, Mitra A (2017) Mixotrophy in the marine plankton. Annu Rev Mar Sci 9: 311-335

* Straile D (1997) Gross growth efficiencies of protozoan and metazoan zooplankton and their dependence on food concentration, predator-prey weight ratio, and taxonomic group. Limnol Oceanogr 42:1375-1385

* Stukel MR, Landry MR, Selph KE (2011) Nanoplankton mixotrophy in the eastern equatorial Pacific. Deep Sea Res II 58:378-386

Sverdrup HU, Johnson MW, Fleming RH (1942) The oceans: their physics, chemistry, and general biology, Vol 7. Prentice-Hall, New York, NY

* Swalwell JE, Ribalet F, Armbrust EV (2011) SeaFlow: a novel underway flow-cytometer for continuous observations of phytoplankton in the ocean. Limnol Oceanogr Methods 9:466-477

* Terrado R, Pasulka AL, Lie AAY, Orphan VJ, Heidelberg KB, Caron DA (2017) Autotrophic and heterotrophic 
acquisition of carbon and nitrogen by a mixotrophic chrysophyte established through stable isotope analysis. ISME J 11:2022-2034

Thaben PF, Westermark PO (2014) Detecting rhythms in time series with RAIN. J Biol Rhythms 29:391-400

Tsai AY, Chin WM, Chiang KP (2009) Diel patterns of grazing by pigmented nanoflagellates on Synechococcus spp. in the coastal ecosystem of subtropical western Pacific. Hydrobiologia 636:249-256

Unrein F, Massana R, Alonso-Sáez L, Gasol JM (2007) Significant year-round effect of small mixotrophic flagellates on bacterioplankton in an oligotrophic coastal system. Limnol Oceanogr 52:456-469

Unrein F, Gasol JM, Not F, Forn I, Massana R (2014) Mixotrophic haptophytes are key bacterial grazers in oligotrophic coastal waters. ISME J 8:164-176

Urabe J, Gurung TB, Yoshida T, Sekino T, Nakanishi M, Maruo M, Nakayama E (2000) Diel changes in phagotrophy by Cryptomonas in Lake Biwa. Limnol Oceanogr 45:1558-1563

Verity PG (1991) Feeding in planktonic protozoans: evidence for non-random acquisition of prey. J Protozool 38: 69-76

Verity PG, Stoecker DK, Sieracki ME, Nelson JR (1993) Grazing, growth and mortality of microzooplankton dur-

Editorial responsibility: Robert Sanders, Philadelphia, Pennsylvania, USA ing the 1989 North Atlantic spring bloom at $47^{\circ} \mathrm{N}, 18^{\circ} \mathrm{W}$. Deep-Sea Res 40:1793-1814

WWard BA, Follows MJ (2016) Marine mixotrophy increases trophic transfer efficiency, mean organism size, and vertical carbon flux. Proc Natl Acad Sci USA 113: 2958-2963

*Wilken S, Choi CJ, Worden AZ (2020) Contrasting mixotrophic lifestyles reveal different ecological niches in two closely related marine protists. J Phycol 56:52-67

*Wilson ST, Aylward FO, Ribalet F, Barone B and others (2017) Coordinated regulation of growth, activity and transcription in natural populations of the unicellular nitrogen-fixing cyanobacterium Crocosphaera. Nat Microbiol 2:17118

* Wootton EC, Zubkov MV, Jones DH, Jones RH, Martel CM, Thornton CA, Roberts EC (2007) Biochemical prey recognition by planktonic protozoa. Environ Microbiol 9: 216-222

Zubkov MV, Tarran GA (2008) High bacterivory by the smallest phytoplankton in the North Atlantic Ocean. Nature 455:224-226

* Zwirglmaier K, Spence E, Zubkov MV, Scanlan DJ, Mann NH (2009) Differential grazing of two heterotrophic nanoflagellates on marine Synechococcus strains. Environ Microbiol 11:1767-1776

Submitted: May 26, 2020; Accepted: September 7, 2020 Proofs received from author(s): November 19, 2020 